SpringerLink Header: Pathogenesis of Type 1 Diabetes (A Pugliese and SJ Richardson, Section Editors)

\title{
The Effect of Age on the Progression and Severity of Type 1 Diabetes: Potential Effects on Disease Mechanisms
}

Pia Leete ${ }^{1}$, Roberto Mallone², Sarah J. Richardson ${ }^{3}$, Jay M. Sosenko ${ }^{4}$, Maria J. Redondo 5 , and Carmella Evans-Molina ${ }^{6}$

${ }^{1}$ Islet Exeter (IBEx), Institute of Biomedical and Clinical Sciences, University of Exeter Medical School, Exeter, UK; P.Leete@exeter.ac.uk

2INSERM U1016, CNRS UMR8104, Cochin Institute, Paris Descartes University, Sorbonne Paris Cité; Assistance Publique Hôpitaux de Paris, Service de Diabétologie, Cochin Hospital, Paris, France; roberto.mallone@inserm.fr

${ }^{3}$ Islet Exeter (IBEx), Institute of Biomedical and Clinical Sciences, University of Exeter Medical School, Exeter, UK; S.Richardson@exeter.ac.uk

${ }^{4}$ Department of Medicine and the Diabetes Research Institute, Leonard Miller School of Medicine, University of Miami, Miami, FL, USA; jsosenko@med.miami.edu

${ }^{5}$ Department of Pediatrics, Baylor College of Medicine and the Texas Children's Hospital, Houston, TX, USA; redondo@bcm.edu

${ }^{6}$ Departments of Medicine and Pediatrics, and the Herman B Wells Center for Pediatric Research, Indiana University School of Medicine and the Roudebush VA Medical Center, Indianapolis, IN, USA; cevansmo@iu.edu

To Whom Correspondence Should be Addressed: Carmella Evans-Molina, MD, PhD (cevansmo@iu.edu), Indiana University School of Medicine, 635 Barnhill Drive, MS 2031A, Indianapolis, IN 46202; Telephone: (317) 274-4145, Fax (317) 274-4107

Keywords: Type 1 diabetes, age, C-peptide, $\beta$ cell, autoimmunity

This is the author's manuscript of the article published in final edited form as:

Leete, P., Mallone, R., Richardson, S. J., Sosenko, J. M., Redondo, M. J., \& Evans-Molina, C. (2018). The Effect of Age on the Progression and Severity of Type 1 Diabetes: Potential Effects on Disease Mechanisms. Current Diabetes Reports, 18(11), 115. https://doi.org/10.1007/s11892-018-1083-4 


\section{ABSTRACT}

Purpose of review: To explore the impact of age on type 1 diabetes (T1D) pathogenesis.

Recent findings: Children progress more rapidly from autoantibody positivity to T1D and have lower C-peptide levels compared to adults. In histological analysis of post-mortem pancreata, younger age of diagnosis is associated with reduced numbers of insulin containing islets and a hyper-immune CD20 hi infiltrate. Compared to adults, children exhibit decreased immune regulatory function and increased engagement and trafficking of autoreactive CD8 ${ }^{+}$ T-cells, and age-related differences in $\beta$-cell vulnerability may also contribute to the more aggressive immune phenotype observed in children. HLA and non-HLA genetic loci that influence multiple disease characteristics, including age of onset, are being increasingly characterized.

Summary: The exception of T1D as an autoimmune disease more prevalent in children than adults results from a combination of immune, metabolic, and genetic factors. Age-related differences in T1D pathology have important implications for better tailoring of immunotherapies. 


\section{Introduction}

Type 1 diabetes is a disease characterized by autoimmune-mediated destruction of the pancreatic $\beta$ cell that affects $0.3 \%$ of the population (1). The incidence of T1D peaks between 5-9 years of age, with a second peak occurring near puberty (2). Globally, incidence is increasing at rate of approximately $2-3 \%$ per year $(3,4)$, and recent data have identified a disproportionate increase among very young children $<5$ years of age $(2,5,6)$. Thus, T1D stands alone in the pantheon of autoimmune disease for its incidence, which decreases rather than increases with age. In addition to age-related heterogeneity in disease epidemiology, accumulating evidence also suggests a potential contribution of age on T1D pathophysiology and response to disease-modifying therapies. Here, we review the genetic, metabolic, and immunologic underpinnings of the impact of age on T1D risk, progression, and aetiology.

\section{The impact of age on the natural history of T1D}

Longitudinally monitoring of birth cohorts of children with high genetic risk based on family history and HLA genotype have offered unique insight into the progression of T1D. Most notably, observations from a variety of these cohorts highlight an important impact of age on the development of islet autoantibodies, which serve as a sentinel of immune activation against the $\beta$ cell. Analysis of the German BABYDIAB and BABYDIET cohorts identified a peak incidence of autoantibody seroconversion between 9 months and 2 years of age. Children who seroconverted at these younger ages had a higher risk of developing T1D and developed T1D faster than children with a later age of seroconversion (7). Similar findings were seen in the Environmental Determinants of Diabetes in the Young (TEDDY) study, which is a birth cohort study based in the U.S. and Europe. Within the TEDDY cohort, the peak incidence of islet autoantibodies also occurred around 9 months of age. In addition, differences in the timing of autoantibody type were observed in TEDDY participants, with the peak incidence of insulin autoantibodies occurring during the first year of life. In contrast, the peak incidence of GAD autoantibodies occurred later during the second and third years of life

(8). Again, age at the time of multiple autoantibody development influenced progression to 
T1D, with older children exhibiting a lower hazard ratio for T1D development compared to those developing antibodies at a younger age (9). A similar sequencing of antibody development was observed in the Finnish Type 1 Diabetes Prediction and Prevention (DIPP), where the peak incidence of insulin autoantibodies occurred between 2 and 3 years of age, followed by a peak incidence of GAD autoantibodies between 3 and 5 years (10).

The TrialNet Pathway to Prevention (TNPTP) study and its precursor the Diabetes Prevention Trial-Type 1 (DPT-1) have both undertaken massive screening efforts in relatives of persons with T1D to identify cohorts of autoantibody positive adults and children (11-14). These studies differ from birth cohorts, in that participants are identified in a cross-sectional manner. Therefore, the full duration of autoantibody positivity prior to study enrollment is not known. Nonetheless, data from both cohorts supports the idea that age is inversely predictive of T1D risk once autoantibody positivity is established. Adults are at lower risk of progression compared to children, and even among children, the risk is lower in older children. An inverse association of T1D risk with age is also present among those with abnormal glucose tolerance. In DPT-1, among participants who developed incident dysglycemia, those who were $<13$ years were at much higher risk than those $>13$ years to subsequently develop T1D (15). In the TNPTP, the risk according to age among those dysglycemic was not as linear as for the full cohort; the decline in risk for T1D was especially evident among those who were over 20 years (16). Notably, the decreasing risk of T1D with age has had utility as one of the components of a risk score for the prediction of T1D that has been utilized and validated in both studies (17, 18).

\section{Age and metabolic progression in T1D}

Age has a clear influence on the rapidity of progression from the time of autoantibody positivity to the development of a clinical diagnosis of T1D. Of additional interest is how patterns of C-peptide decline vary amongst different age groups during disease evolution. Given the inherent challenges in identifying large cohorts of autoantibody-positive individuals around the time of seroconversion, the impact of age on the longitudinal loss of C-peptide in 
at-risk individuals during stage 1 (autoantibody-positive, normoglycemic) and 2 (autoantibody-positive, dysglycemic) T1D has been difficult to decipher. Amongst longitudinal studies, differences according to age were either not examined or have been limited by low numbers of subjects for assessing the extent to which progression patterns vary with age $(19,20)$. In a recent analysis of TNPTP data, patterns of C-peptide loss and glycemia were examined in autoantibody-positive subjects who progressed to T1D after $<5$ years and $\geq 5$ years of follow-up. Progressors with $<5$ years of follow-up were younger at study entry had a younger age of diabetes diagnosis compared to progressors with $\geq 5$ years of follow-up (median of $11.6 \mathrm{yrs}$ at T1D onset in progressors $<5 \mathrm{vs}$. a median of $17.0 \mathrm{yrs}$ in progressors $\geq 5$ ). Remarkably, patterns of $\mathrm{C}$-peptide loss and increased glycemia within three years of diagnosis were nearly identical between the two groups, raising the possibility that within this proximity to diagnosis, metabolic progression follows a stereotypical course of decline that is independent of age (21).

At the time of stage 3 T1D onset (i.e. clinical hyperglycemia), absolute values of Cpeptide differ between youth and adult populations, with youth exhibiting significantly lower absolute serum and urinary C-peptide levels $(22,23)$. Similarly, amongst individuals with T1D diagnosed within 10 weeks, higher insulin secretory rates during a 4-hour mixed meal tolerance test correlated with older age at presentation (24). Consistent with this, younger children are more likely to present with ketoacidosis at the time of diagnosis $(25,26)$. Those with an earlier onset have also been described to have a shorter period of partial clinical remission or a "honeymoon" period (27). Whether these observed differences in C-peptide levels are physiological (i.e. due to differences in adiposity or insulin resistance) or represent differences in disease pathology remain unclear. Interestingly, in an ethnically diverse pediatric cohort, obese and overweight children had higher residual $\beta$-cell function compared to lean children at the time of T1D diagnosis (28). Surprisingly, there is very little information regarding C-peptide and age relationships in non-obese, non-diabetic children for comparison.

Longitudinal relationships between age and C-peptide loss after stage 3 disease onset have been examined in several cohorts, and analyses have yielded somewhat differing 
results. In subjects who participated in the placebo arms of several TrialNet intervention studies, longitudinal follow-up was initiated within 3 months of diagnosis. Slopes of decline in the C-peptide area under curve values from mixed meal tolerance tests over 2 years of followup tended to be parallel for the age groups among children, whereas the slope of decline in adults was flatter (29). In another longitudinal TrialNet study, recently diagnosed participants were followed for up to 4 years. Endpoints included peak stimulated C-peptide levels $\leq 0.2$ $\mathrm{nmol} / \mathrm{L}$ and progression to undetectable C-peptide levels. When groups were separated according to age, the survival curves for those endpoints became less steep with age (30). Thus, both TrialNet post-diagnostic studies showed that C-peptide is better maintained in older individuals, a pattern which appeared to persist for at least 4 years after diagnosis.

A recent analysis of two UK cohorts with diabetes of long duration identified two distinct phases of $\mathrm{C}$-peptide decline. The first was characterized by an initial exponential fall over the first 7 years, followed by a period of relative stability. In contrast to the TrialNet studies, neither the overall pattern or duration of these two phases differed in subjects above and below the median age of diagnosis in the cohort (10.8 years) (31). In a Swedish cohort, Wallensteen et al. examined the slope of C-peptide loss in a cohort of children. Overall, they found the rate of fall of the post-prandial C-peptide was $-0.019 \mathrm{nmol} / \mathrm{month}$. Age at onset had no correlation with the observed rate of change. Moreover, the rate of change was nearly parallel in children aged 1-5, 6-11, and 12-17 years of age (32). The reason for these discrepant results amongst different cohorts is unclear, but there are several possibilities to consider. The first is that measures of C-peptide and methods used to model data differ between studies. There are also important differences in the analytic platforms used to measure C-peptide. Finally, differences in the demographic and ethnic characteristics of the cohorts should also be considered, and additional studies are needed. 


\section{Analysis of human donor pancreata provides insights into age-related T1D heterogeneity}

Notwithstanding these uncertainties, recent studies of human pancreata have provided unique tissue-level insight into the impact of age on T1D pathophysiology. The human pancreas is a challenging organ to study and is only biopsied under exceptional circumstances, for which T1D is not one. The majority of studies of T1D pancreata have therefore been completed on post-mortem (33) or transplant grade organ donor material (34), although few selected donor biopsies have been performed (35). It is these rare samples that have provided insight into striking heterogeneity in the pancreatic pathology and shown these differences are often strongly associated with age. To understand pathology, though, we must first understand the healthy pancreas as this is critical to benchmarking the progression of disease. Whilst research into the healthy human pancreas is not as prolific as it is in disease, we now understand that $\beta$-cell mass is relatively stable from 20 years of age; that $\beta$-cell replication is low and apoptosis almost undetectable (36-39). Events under the age of 20 years are perhaps less well understood, although it is clear that significant increases in $\beta$-cell mass and proliferation are observed in the early years of life (37-39). Finally, the islet size, islet architecture, and connectivity of endocrine cells to one another can change during development (39-42), and the impact of these alterations on the development of disease is still largely unknown.

In T1D, $\beta$-cell destruction is linked to a targeted lymphocytic invasion of the islets, termed insulitis. Insulitis is more severe at, or close to, the initial diagnosis $(33,43)$, although prolonged inflammation around islets has been documented $(33,44)$. Here too, age-related differences in both the proportion of islets affected with insulitis and the composition of the immune cell infiltrate have been documented $(45,46)$. For example, people who are older at diagnosis can retain significant and often surprising numbers of insulin containing islets (ICls) (46-48), despite having an absolute requirement for exogenous insulin. Indeed, isolated islets collected from older onset donor patients partially recovered their insulin secretory profile after 
7 days in culture, suggesting that, in a non-diabetogenic environment, these residual islets could be returned to health (49) - a hopeful proposition for the future.

It is widely accepted that, within the insulitic lesion, the CD8+ T cells are the main aggressors, whilst CD20+ $\mathrm{B}$ lymphocytes and CD4+ T cells, as well as macrophages, are also present $(44-46,50)$. However, the number of immune cells present around a given islet, and the proportions of these cells relative to one another, differs markedly between persons with T1D. Intriguingly in those people diagnosed with T1D $\leq 7 y$, the majority of the residual ICls ( $75 \%$ at diagnosis) have evidence of insulitis (defined as $\geq 15$ CD45+ cells in or around the islet periphery $(51,52))$ that contains high numbers of CD8+ T cells and CD20+ B cells, but relatively low numbers of CD4+ T cells (46). As such the ratio of the average number of CD20+ B cells to CD4+ T cells is high (>1). These cases have been termed hyper-immune or CD20 ${ }^{\mathrm{Hi}}$. In contrast in individuals who are diagnosed beyond their mid-teens, a relatively mild infiltration of only a proportion of residual ICls ( $25 \%$ at diagnosis) was found. In these, although the predominant cell type was still CD8+ $T$ cells, the CD4+ $T$ cells typically outnumbered the CD20+ $\mathrm{B}$ cells, such that the CD20+ B: CD4+ T ratio was low $(<1)(46)$. These cases have been termed pauci-immune or CD20 ${ }^{\mathrm{Lo}}$. In keeping with these findings, examination of $151 \mathrm{~T} 1 \mathrm{D}$ subjects from the EADB cohort and 116 T1D donors from the nPOD cohort, irrespective of disease duration, showed that those diagnosed beyond their mid-teens were far more likely to still contain residual ICls when compared with those diagnosed $\leq 7 y(46)$. Interestingly, the histopathological observations appear to mirror those seen when assessing residual $\beta$-cell function using C-peptide measurements in the blood or urine, in that C-peptide levels are significantly lower in younger individuals (22-24).

\section{Peripheral immune signatures of T1D vary by age}

Peripheral correlates of these histological findings in the pancreas have been tested in a number of studies. Culina et al. (53) recently reported that circulating islet-reactive (HLAA2 multimer-positive) $C D 8^{+} \mathrm{T}$ cells are strikingly similar between T1D and healthy donors in terms of frequency and history of antigen encounter. Indeed, the other surprising feature of 
these islet-reactive CD8+ T cells detected in peripheral blood was their predominantly naïve phenotype, implying that this T-cell repertoire is potentially autoreactive, but not actively involved in the autoimmune process. The T-cell fraction participating to disease seemed instead sequestered in the pancreas, where higher densities of islet-reactive $\mathrm{CD}^{+} \mathrm{T}$ cells have been found in T1D donors compared to healthy and T2D controls. Importantly, these features applied to islet-reactive CD8 ${ }^{+} \mathrm{T}$ cells recognizing either known $\beta$-cell antigens (53) or novel ones identified as sources of peptides naturally processed and presented by $\beta$ cells (54). These novel antigens, identified by HLA peptidomics, included urocortin-3, the insulin gene enhancer protein ISL-1, and an islet amyloid polypeptide (IAPP) ${ }_{15-17 / 5-10}$ epitope generated by the fusion of two non-contiguous amino acid sequences (54). Circulating CD8 ${ }^{+} \mathrm{T}$ cells recognizing the $\mathrm{ZnT}_{186-194}$ epitope were subsequently compared between new-onset T1D children and adults (53). Their frequency was higher in children versus adults, but again irrespective of T1D status. The same pattern was also observed for $\mathrm{CD}^{+} \mathrm{T}$ cells recognizing the extra-pancreatic melanocyte self-epitope Melan $A_{26-35}$, but the corresponding ZnT8reactive populations were more antigen-experienced in T1D children. These results suggest that compared to adults, children harbor a larger autoimmune $\mathrm{CD}^{+} \mathrm{T}$-cell repertoire against different self-antigens, but that the islet-reactive repertoire is preferentially engaged in T1D children.

A similar heterogeneity between T1D children and adults has been described for isletreactive $\mathrm{CD}^{+}{ }^{+} \mathrm{T}$-cell responses detected by ELISpot, which were more polarized toward secretion of the regulatory cytokine interleukin (IL)-10 in patients with older age at T1D diagnosis (55). By studying two distinct groups of children and adolescents with recent-onset T1D, Arif et al. (45) described two clusters of patients characterized by pro-inflammatory (IFN$\mathrm{V}^{+}$CD4+ ${ }^{+}$-cell ELISpot responses, multi-autoantibody $\left.{ }^{+}\right)$and partially regulated (IL-10+, pauciautoantibody+) responses in peripheral blood.

Which mechanisms may underlie the more aggressive islet autoimmunity observed in T1D children? The first possibility is that immune regulation may be more effective in older 
patients, resulting in a milder autoimmunity and, possibly, a clinical onset later in life. This hypothesis is supported by the endotypes described in the pancreas (45) and by the observation that the frequency of $T$ regulatory cells increases with age (56). In this respect, the age exception of T1D compared to other autoimmune diseases suggests that tolerance to $\beta$ cells may critically rely on suppression by T regulatory cells.

The second possibility is that $\beta$ cells may play a central role of their own. This role may include modulation of the autoimmune aggressiveness, which may be licensed by the vulnerability and 'visibility' that $\beta$ cells offer to the autoreactive T-cell repertoire. In this scenario, tolerance to $\beta$ cells may also depend on T-cell ignorance, as suggested in the mouse $(57,58)$. The loss of such ignorance may be favoured by $\beta$-cell stressors, such as islet-tropic enteroviruses and the metabolic demands imposed by growth. These stressors could exert their effects by inducing variable degrees of $\beta$-cell death and inflammation, thus making antigens visible to autoreactive T cells under suitable immunogenic conditions. In this respect, the age exception of T1D autoimmunity may be explained by the fact that these $\beta$-cell stressors are more frequently encountered during childhood. Consistent with this notion, proinsulin/C-peptide ratios were measured in TrialNet progressors to T1D approximately 12 months prior to the development of Stage 3. Values were highest in the youngest age group, suggesting that levels of $\beta$-cell stress may be higher in young children during Stages 1 and 2 disease (59).

\section{Genetic explanations for age-related T1D heterogeneity}

Data indicate that the above age-related heterogeneity in T1D may have a genetic basis. Twin studies offered the first evidence of the influence of genetics not only on T1D development but also on the age at diagnosis. Fava et al. studied monozygotic (i.e., identical) and dizygotic (i.e. non-identical) twin pairs and sibling pairs, who were concordant for T1D (i.e., both twins or both siblings had the disease). The correlation in the diagnosis age was stronger in monozygotic than dizygotic twins, but it was not significant between non-twin siblings, (60) underscoring the contribution of genetic factors to age of T1D onset. In a series 
of initially non-diabetic monozygotic twins of patients with T1D $(n=187)$ who were followed for a median of 17.7 years (61), younger age at diagnosis in the index twin was a risk factor for T1D in the initially non-diabetic twin; the twins of patients who were diagnosed at age $\geq 25$ had approximately half the risk of T1D of twins of patients who were diagnosed at $<14$ years.

The effect of specific genetic factors, in particular, the MHC, IL-2 (IL2) (4q27, rs2069763) and renalase (RNLS) (10q23.31, rs10509540) gene regions, on the age of T1D diagnosis was first reported by Howson et al (62). More recently, using a genome wide approach to address this question, a recent study investigated a large number of SNPs, included in the ImmunoChip, in 16,015 individuals with T1D, 92\% diagnosed $<20$ years of age, collected through six different international cohorts (63). This study concluded that the HLA complex in the $6 p 21$ region, in particular the rs9273363 SNP that tags the HLA DQB1*03:02 haplotype, and the 6q22.33 region, which contains the genes encoding protein tyrosine phosphatase receptor kappa (PTPRK) and thymocyte-expressed molecule involved in selection (THEMIS), were associated with younger age of T1D onset. Participants who were homozygous for the allele associated with younger age of onset in both regions were over four years younger at T1D diagnosis than those who were homozygous for the non-risk allele at both loci. Furthermore, while not associated with T1D risk overall in this or prior studies, the SNP most strongly linked with age of diagnosis in the $6 q 22.33$ region, rs72975913, was also associated with T1D risk in children under age 5. This SNP has also been previously reported in association with celiac disease, which might contribute to explain the link between celiac disease and young age at T1D diagnosis (64). Howson et al. also found that DR4 and DR3/DR4, but not DR3, were associated with younger age at onset (65). This is consistent with other reports that individuals who are older at T1D onset are less likely to have T1Dassociated HLA alleles (66).

The effect of genetics on the heterogeneity of autoimmune diabetes across ages is also illustrated by latent autoimmune diabetes in adults (LADA). LADA is usually defined as autoimmune diabetes that is diagnosed after age 30 and does not require insulin treatment for 
the first 6 months. Mishra et al. studied the associations of T1D and type 2 diabetes (T2D) loci with LADA, compared with childhood onset T1D, adult onset T2D and controls (67). These authors found that although LADA is genetically closer to childhood onset T1D than to T2D, there are differences. For instance, LADA has weaker association with HLA and higher with INS, while PTN22 and SH2B3 were similarly associated with LADA and childhood-onset T1D. Among the 71 T2D-linked loci, only HNF1A was associated with LADA in this study, although prior reports showed an association with T2D-linked TCF7L2 variants as well. T1D and T2D genetic risk scores (GRS) facilitate the comparison of the genetic load by combining either T1D or T2D SNPs, respectively, into a single number (68). The authors found that the T1D GRS was more discriminative of LADA than the T2D GRS, although there was an important T2D genetic load as well.

In a study that evaluated the performance of the T1D GRS to predict progression along pre-clinical T1D stages, the T1D GRS was a significant predictor of progression from single to multiple positive autoantibodies in individuals younger than age 35 but not in older participants who are at a lower risk of T1D overall (69). Thus, T1D loci are stronger predictors in the form of T1D that develops earlier in life, while later onset T1D may have additional genetic determinants. For instance, the association between the T2D-linked transcription factor 7 like2 (TCF7L2) variants and milder autoimmunity, as reflected by expression of a single autoantibody at T1D onset $(70,71)$ was restricted to participants $\geq 12$ years $(72)$. It is possible that in individuals with weaker, slowly progressive islet autoimmunity, this T2D-associated SNP accelerates the progression to diabetes, although still not younger than 12 , while the aggressive islet autoimmunity and subsequent profound insulin deficiency often seen at younger ages curtails the potential effect of additional diabetogenic factors such as TCF7L2.

\section{Therapeutic implications of age-related heterogeneity in T1D}

Over the past 30 years, a number of agents have been tested as disease-modifying therapies for T1D in both secondary and primary prevention strategies. These clinical trial 
efforts have focused on induction of tolerance through administration of self-antigen or on the modulation of T-cell, B-cell and cytokine responses. To date, only a handful of interventions have shown efficacy in preserving C-peptide secretion in randomized-placebo controlled trials. Interestingly, in several of these successful trials, important age-related differences in treatment effects have been observed. When administered at T1D onset, anti-CD3 therapy with two different drugs (otelixizumab and tepluzimab) led to greater preservation of C-peptide in younger individuals $(73,74)$. Younger trial participants were also more likely to exhibit a partial response to alefacept, a fusion protein that binds CD2 and targets CD4+ and CD8+ effector memory T cells $(75,76)$. Similarly, children exhibited greater responses to rituximab, which targets B cells (77) and the co-stimulatory modulator, abatacept $(16,78)$.

\section{Conclusions}

Age has been shown to have a profound impact on T1D epidemiology, risk, and progression; in all cases, youth are more greatly impacted than adults. These differences likely result from a combination of immunologic, metabolic, and genetic factors. However, at present, we have only a cursory understanding of the underlying mechanisms responsible for

these differences. Clinical trial experience suggests that some, but not all, immune interventions exhibit greater effects in children compared to adults. This observation raises several possibilities that must be considered as the field works to identify potential diseasemodifying therapies. The first possibility is that pathogenesis is truly different between adults and children and that past interventions have been more effective in addressing pathology present in youth. The second possibility is that the immune system is more pliable in children, therefore accounting for the higher observed efficacy in younger participants. A final possibility is that greater effects are observed in younger subjects, where C-peptide decline after stage 3 diagnosis is more pronounced. Additional mechanistic studies are needed to address these possibilities and to monitor immunologic responses between responders and non-responders in trials where age-related differences in outcome have been observed. In the future, these data should be leveraged to design trials that test distinct interventions between children and 
adults and to ensure continued clinical trial efforts in children, where a greater prospect of benefit may exist.

\section{ACKNOWLEDGMENTS}

We are pleased to acknowledge financial support from the European Union"s Seventh Framework Programme PEVNET ([FP7/2007-2013)] under grant agreement number 261441. The participants of the PEVNET consortium are described at http://www.uta.fi/med/pevnet/publications.html. Additional support was from a JDRF research grants awarded to the network of Pancreatic Organ Donors - Virus (nPOD-V) consortium (JDRF 25-2012-516 and JDRF-3-SRA-2017-492-A-N) and a JDRF Career Development Award (5-CDA-2014-221-A-N), an MRC Project Grant (MR/P010695/1) and project grant from Diabetes UK (16/0005480) all to SJR.This work was also supported by $\mathrm{NIH}$ grants R01 DK093954 and UC4 DK 104166 (to C.E.M.), U01 DK103180 (to M.R.), VA Merit Award I01BX001733 (to C.E.M.), a JDRF Strategic Research Agreement (2-SRA2018-493-A-B), and gifts from the Sigma Beta Sorority, the Ball Brothers Foundation, the George and Frances Ball Foundation, and the Holiday Management Foundation, all to C.E.M. R.M. received grants from the JDRF (1-PNF-2014-155-A-V, 2-SRA-2016-164-Q-R), the Agence Nationale de la Recherche (ANR-2015-CE17-0018-01) and by the Innovative Medicines Initiative 2 Joint Undertaking (INNODIA, 115797), which receives support from the EU Horizon 2020 program, the European Federation of Pharmaceutical Industries and Associations, JDRF, and the Helmsley Charitable Trust.

\section{Compliance with Ethical Standards}

\section{Conflict of Interest}

Pia Leete, Roberto Mallone, Sarah J. Richardson, Jay M. Sosenko, Maria J. Redondo, and Carmella Evans-Molina declare that they have no conflict of interest.

\section{Human and Animal Rights and Informed Consent}

This article does not contain any studies with human or animal subjects performed by any of the authors. 


\section{REFERENCES}

Papers of particular interest, published recently, have been highlighted as:

- Of importance

•• Of major importance

1. DiMeglio LA, Evans-Molina C, Oram RA. Type 1 diabetes. Lancet. 2018 Jun 16;391(10138):2449-62. PubMed PMID: 29916386. Epub 2018/06/20.

2. Stanescu DE, Lord K, Lipman TH. The epidemiology of type 1 diabetes in children. Endocrinology and metabolism clinics of North America. 2012 Dec;41(4):679-94. PubMed PMID: 23099264. Epub 2012/10/27. eng.

3. Maahs DM, West NA, Lawrence JM, Mayer-Davis EJ. Epidemiology of type 1 diabetes. Endocrinology and metabolism clinics of North America. 2010 Sep;39(3):481-97. PubMed PMID: 20723815. Pubmed Central PMCID: 2925303.

4. Mayer-Davis EJ, Lawrence JM, Dabelea D, Divers J, Isom S, Dolan L, et al. Incidence Trends of Type 1 and Type 2 Diabetes among Youths, 2002-2012. The New England journal of medicine. 2017 Apr 13;376(15):1419-29. PubMed PMID: 28402773. Pubmed Central PMCID: 5592722.

5. Chobot A, Polanska J, Brandt A, Deja G, Glowinska-Olszewska B, Pilecki O, et al. Updated 24-year trend of Type 1 diabetes incidence in children in Poland reveals a sinusoidal pattern and sustained increase. Diabetic medicine : a journal of the British Diabetic Association. 2017 Sep;34(9):1252-8. PubMed PMID: 28257151.

6. Lipman TH, Levitt Katz LE, Ratcliffe SJ, Murphy KM, Aguilar A, Rezvani I, et al. Increasing incidence of type 1 diabetes in youth: twenty years of the Philadelphia Pediatric Diabetes Registry. Diabetes care. 2013 Jun;36(6):1597-603. PubMed PMID: 23340888. Pubmed Central PMCID: PMC3661835. Epub 2013/01/24.

7. Ziegler AG, Bonifacio E, Group B-BS. Age-related islet autoantibody incidence in offspring of patients with type 1 diabetes. Diabetologia. 2012 Jul;55(7):1937-43. PubMed PMID: 22289814.

8. Krischer JP, Lynch KF, Lernmark A, Hagopian WA, Rewers MJ, She JX, et al. Genetic and Environmental Interactions Modify the Risk of Diabetes-Related Autoimmunity by 6 Years of Age: The TEDDY Study. Diabetes care. 2017 Sep;40(9):1194-202. PubMed PMID: 28646072. Pubmed Central PMCID: PMC5566280. Epub 2017/06/25.

9. Krischer JP, Liu X, Lernmark A, Hagopian WA, Rewers MJ, She JX, et al. The Influence of Type 1 Diabetes Genetic Susceptibility Regions, Age, Sex, and Family History on the Progression From Multiple Autoantibodies to Type 1 Diabetes: A TEDDY Study Report. Diabetes. 2017 Dec;66(12):3122-9. PubMed PMID: 28903990. Pubmed Central PMCID: PMC5697938. Epub 2017/09/15.

10. Ilonen J, Hammais A, Laine AP, Lempainen J, Vaarala O, Veijola R, et al. Patterns of beta-cell autoantibody appearance and genetic associations during the first years of life. Diabetes. 2013 Oct;62(10):3636-40. PubMed PMID: 23835325. Pubmed Central PMCID: PMC3781470. Epub 2013/07/10.

11. Battaglia M, Anderson MS, Buckner JH, Geyer SM, Gottlieb PA, Kay TWH, et al. Understanding and preventing type 1 diabetes through the unique working model of TrialNet. Diabetologia. 2017 Nov;60(11):2139-47. PubMed PMID: 28770323. Pubmed Central PMCID: PMC5838353. Epub 2017/08/05.

12. Greenbaum CJ, Speake C, Krischer J, Buckner J, Gottlieb PA, Schatz DA, et al. Strength in Numbers: Opportunities for Enhancing the Development of Effective Treatments for Type 1 Diabetes-The TrialNet Experience. Diabetes. 2018 May 16. PubMed PMID: 29769238. Epub 2018/05/18.

13. Mahon JL, Sosenko JM, Rafkin-Mervis L, Krause-Steinrauf H, Lachin JM, Thompson C, et al. The TrialNet Natural History Study of the Development of Type 1 Diabetes: 
objectives, design, and initial results. Pediatric diabetes. 2009 Apr;10(2):97-104. PubMed PMID: 18823409.

14. Writing Committee for the Type 1 Diabetes TrialNet Oral Insulin Study G, Krischer JP, Schatz DA, Bundy B, Skyler JS, Greenbaum CJ. Effect of Oral Insulin on Prevention of Diabetes in Relatives of Patients With Type 1 Diabetes: A Randomized Clinical Trial. JAMA : the journal of the American Medical Association. 2017 Nov 21;318(19):1891-902. PubMed PMID: 29164254. Pubmed Central PMCID: PMC5798455. Epub 2017/11/23.

15. Sosenko JM, Palmer JP, Rafkin-Mervis L, Krischer JP, Cuthbertson D, Mahon J, et al. Incident dysglycemia and progression to type 1 diabetes among participants in the Diabetes Prevention Trial-Type 1. Diabetes care. 2009 Sep;32(9):1603-7. PubMed PMID: 19487644. Pubmed Central PMCID: PMC2732147. Epub 2009/06/03.

16. Wherrett DK, Chiang JL, Delamater AM, DiMeglio LA, Gitelman SE, Gottlieb PA, et al. Defining pathways for development of disease-modifying therapies in children with type 1 diabetes: a consensus report. Diabetes care. 2015 Oct;38(10):1975-85. PubMed PMID: 26404927. Pubmed Central PMCID: PMC4876737. Epub 2015/09/26.

17. Sosenko JM, Skyler JS, Mahon J, Krischer JP, Beam CA, Boulware DC, et al. Validation of the Diabetes Prevention Trial-Type 1 Risk Score in the TrialNet Natural History Study. Diabetes care. 2011 Aug;34(8):1785-7. PubMed PMID: 21680724. Pubmed Central PMCID: 3142063. Epub 2011/06/18. eng.

18. Sosenko JM, Skyler JS, Mahon J, Krischer JP, Beam CA, Boulware DC, et al. The Application of the Diabetes Prevention Trial-Type 1 Risk Score for Identifying a Preclinical State of Type 1 Diabetes. Diabetes care. 2012 Jul;35(7):1552-5. PubMed PMID: 22547092. Pubmed Central PMCID: 3379597. Epub 2012/05/02. Eng.

19. Sosenko JM, Palmer JP, Rafkin LE, Krischer JP, Cuthbertson D, Greenbaum CJ, et al. Trends of earlier and later responses of $\mathrm{C}$-peptide to oral glucose challenges with progression to type 1 diabetes in diabetes prevention trial-type 1 participants. Diabetes care. 2010 Mar;33(3):620-5. PubMed PMID: 20032282. Pubmed Central PMCID: PMC2827520.

20. Sosenko JM, Palmer JP, Greenbaum CJ, Mahon J, Cowie C, Krischer JP, et al. Patterns of metabolic progression to type 1 diabetes in the Diabetes Prevention Trial-Type 1. Diabetes care. 2006 Mar;29(3):643-9. PubMed PMID: 16505520. Epub 2006/03/01.

21. Evans-Molina C, Sims EK, DiMeglio LA, Ismail HM, Steck AK, Palmer JP, et al. $\beta$ cell dysfunction exists more than 5 years before type 1 diabetes diagnosis. JCI Insight. 2018;in press.

22. Snorgaard O, Lassen LH, Binder C. Homogeneity in pattern of decline of beta-cell function in IDDM. Prospective study of 204 consecutive cases followed for 7.4 yr. Diabetes care. 1992 Aug;15(8):1009-13. PubMed PMID: 1505301. Epub 1992/08/01. eng.

23. Sosenko JM, Geyer S, Skyler JS, Rafkin LE, Ismail HM, Libman IM, et al. The influence of body mass index and age on C-peptide at the diagnosis of type 1 diabetes in children who participated in the diabetes prevention trial-type 1. Pediatric diabetes. 2018 May;19(3):403-9. PubMed PMID: 29171129. Pubmed Central PMCID: PMC5918232. Epub $2017 / 11 / 25$.

24. Steele C, Hagopian WA, Gitelman S, Masharani U, Cavaghan M, Rother KI, et al. Insulin secretion in type 1 diabetes. Diabetes. 2004 Feb;53(2):426-33. PubMed PMID: 14747294. Epub 2004/01/30.

25. Rodacki M, Pereira JR, Nabuco de Oliveira AM, Barone B, Mac Dowell R, Perricelli $P$, et al. Ethnicity and young age influence the frequency of diabetic ketoacidosis at the onset of type 1 diabetes. Diabetes research and clinical practice. 2007 Nov;78(2):259-62. PubMed PMID: 17478002. Epub 2007/05/05.

26. Hekkala A, Reunanen A, Koski M, Knip M, Veijola R, Finnish Pediatric Diabetes R. Age-related differences in the frequency of ketoacidosis at diagnosis of type 1 diabetes in children and adolescents. Diabetes care. 2010 Jul;33(7):1500-2. PubMed PMID: 20413519. Pubmed Central PMCID: PMC2890349. Epub 2010/04/24.

27. Dost A, Herbst A, Kintzel K, Haberland H, Roth CL, Gortner L, et al. Shorter remission period in young versus older children with diabetes mellitus type 1. Experimental and clinical endocrinology \& diabetes : official journal, German Society of Endocrinology 
[and] German Diabetes Association. 2007 Jan;115(1):33-7. PubMed PMID: 17286232. Epub 2007/02/09.

28. Redondo MJ, Rodriguez LM, Escalante M, O'Brian Smith E, Balasubramanyam A, Haymond MW. Beta cell function and BMI in ethnically diverse children with newly diagnosed autoimmune type 1 diabetes. Pediatric diabetes. 2012 Nov;13(7):564-71. PubMed PMID: 22642603. Epub 2012/05/31.

29. Greenbaum CJ, Beam CA, Boulware D, Gitelman SE, Gottlieb PA, Herold KC, et al. Fall in C-peptide during first 2 years from diagnosis: evidence of at least two distinct phases from composite Type 1 Diabetes TrialNet data. Diabetes. 2012 Aug;61(8):2066-73. PubMed PMID: 22688329. Pubmed Central PMCID: 3402330.

30. Hao W, Gitelman S, DiMeglio LA, Boulware D, Greenbaum CJ, Type 1 Diabetes TrialNet Study G. Fall in C-Peptide During First 4 Years From Diagnosis of Type 1 Diabetes: Variable Relation to Age, HbA1c, and Insulin Dose. Diabetes Care. 2016 Oct;39(10):166470. PubMed PMID: 27422577. Pubmed Central PMCID: 5033079.

31. Shields BM, McDonald TJ, Oram R, Hill A, Hudson M, Leete P, et al. C-Peptide Decline in Type 1 Diabetes Has Two Phases: An Initial Exponential Fall and a Subsequent Stable Phase. Diabetes care. 2018 Jul;41(7):1486-92. PubMed PMID: 29880650. Pubmed Central PMCID: PMC6027962. Epub 2018/06/09.

32. Wallensteen M, Dahlquist G, Persson B, Landin-Olsson M, Lernmark A, Sundkvist G, et al. Factors influencing the magnitude, duration, and rate of fall of B-cell function in type 1 (insulin-dependent) diabetic children followed for two years from their clinical diagnosis. Diabetologia. 1988 Sep;31(9):664-9. PubMed PMID: 3069534. Epub 1988/09/01.

33. Foulis AK, Liddle CN, Farquharson MA, Richmond JA, Weir RS. The histopathology of the pancreas in type 1 (insulin-dependent) diabetes mellitus: a 25-year review of deaths in patients under 20 years of age in the United Kingdom. Diabetologia. 1986 May;29(5):267-74. PubMed PMID: 3522324. Epub 1986/05/01. eng.

34. Campbell-Thompson M, Wasserfall C, Kaddis J, Albanese-O'Neill A, Staeva T, Nierras C, et al. Network for Pancreatic Organ Donors with Diabetes (nPOD): developing a tissue biobank for type 1 diabetes. Diabetes/metabolism research and reviews. 2012 Oct;28(7):608-17. PubMed PMID: 22585677. Pubmed Central PMCID: 3456997.

35. Krogvold L, Edwin B, Buanes T, Ludvigsson J, Korsgren O, Hyoty H, et al. Pancreatic biopsy by minimal tail resection in live adult patients at the onset of type 1 diabetes: experiences from the DiViD study. Diabetologia. 2014 Apr;57(4):841-3. PubMed PMID: 24429579. Epub 2014/01/17. Eng.

36. Saisho Y, Butler AE, Manesso E, Elashoff D, Rizza RA, Butler PC. beta-cell mass and turnover in humans: effects of obesity and aging. Diabetes Care. 2013 Jan;36(1):111-7. PubMed PMID: 22875233. Pubmed Central PMCID: PMC3526241. Epub 2012/08/10.

37. Meier JJ, Butler AE, Saisho Y, Monchamp T, Galasso R, Bhushan A, et al. Beta-cell replication is the primary mechanism subserving the postnatal expansion of beta-cell mass in humans. Diabetes. 2008;57(6):1584-94.

38. Lam CJ, Jacobson DR, Rankin MM, Cox AR, Kushner JA. beta Cells Persist in T1D Pancreata Without Evidence of Ongoing beta-Cell Turnover or Neogenesis. J Clin Endocrinol Metab. 2017 Aug 1;102(8):2647-59. PubMed PMID: 28323930. Pubmed Central PMCID: PMC5546851. Epub 2017/03/23.

39. Gregg BE, Moore PC, Demozay D, Hall BA, Li M, Husain A, et al. Formation of a human beta-cell population within pancreatic islets is set early in life. The Journal of clinical endocrinology and metabolism. 2012 Sep;97(9):3197-206. PubMed PMID: 22745242. Pubmed Central PMCID: PMC3431572.

40. Striegel DA, Hara M, Periwal V. Adaptation of pancreatic islet cyto-architecture during development. Physical biology. 2016;13(2):025004. PubMed PMID: 27063927. 41. Cabrera O, Berman DM, Kenyon NS, Ricordi C, Berggren PO, Caicedo A. The unique cytoarchitecture of human pancreatic islets has implications for islet cell function. Proceedings of the National Academy of Sciences of the United States of America. 2006 Feb 14;103(7):2334-9. PubMed PMID: 16461897. eng. 
42. Kilimnik G, Jo J, Periwal V, Zielinski MC, Hara M. Quantification of islet size and architecture. Islets. 2012 Mar-Apr;4(2):167-72. PubMed PMID: 22653677. Pubmed Central PMCID: PMC3396703. Epub 2012/06/02.

43. In't Veld P. Insulitis in human type 1 diabetes: The quest for an elusive lesion. Islets. 2011 Jul-Aug;3(4):131-8. PubMed PMID: 21606672. Pubmed Central PMCID: 3154446. Epub 2011/05/25. eng.

44. Campbell-Thompson M, Fu A, Kaddis JS, Wasserfall C, Schatz DA, Pugliese A, et al. Insulitis and beta-Cell Mass in the Natural History of Type 1 Diabetes. Diabetes. 2015 Nov 18. PubMed PMID: 26581594.

45. Arif S, Leete P, Nguyen V, Marks K, Nor NM, Estorninho M, et al. Blood and islet phenotypes indicate immunological heterogeneity in type 1 diabetes. Diabetes. 2014 Nov;63(11):3835-45. PubMed PMID: 24939426. Pubmed Central PMCID: 4207393.

46. Leete P, Willcox A, Krogvold L, Dahl-Jørgensen K, Foulis AK, Richardson SJ, et al. Differential insulitic profiles determine the extent of beta cell destruction and the age at onset of type 1 diabetes. Diabetes. 2016 February 8, 2016.

47. Klinke DJ, 2nd. Extent of beta cell destruction is important but insufficient to predict the onset of type 1 diabetes mellitus. PLoS One. 2008;3(1):e1374. PubMed PMID:

18167535. Pubmed Central PMCID: 2147725. Epub 2008/01/03. eng.

48. Keenan HA, Sun JK, Levine J, Doria A, Aiello LP, Eisenbarth G, et al. Residual insulin production and pancreatic beta-cell turnover after 50 years of diabetes: Joslin Medalist Study. Diabetes. 2010 Nov;59(11):2846-53. PubMed PMID: 20699420. Pubmed Central PMCID: 2963543.

49. Krogvold L, Skog O, Sundstrom G, Edwin B, Buanes T, Hanssen KF, et al. Function of isolated pancreatic islets from patients at onset of type 1 diabetes; Insulin secretion can be restored after some days in a non-diabetogenic environment in vitro. Results from the DiViD study. Diabetes. 2015 Feb 12. PubMed PMID: 25677915.

50. Willcox A, Richardson SJ, Bone AJ, Foulis AK, Morgan NG. Analysis of islet inflammation in human type 1 diabetes. Clin Exp Immunol. 2009 Feb;155(2):173-81. PubMed PMID: 19128359. eng.

51. Campbell-Thompson ML, Atkinson MA, Butler AE, Chapman NM, Frisk G, Gianani R, et al. The diagnosis of insulitis in human type 1 diabetes. Diabetologia. 2013 Nov;56(11):2541-3. PubMed PMID: 24006089.

52. Campbell-Thompson ML, Atkinson MA, Butler AE, Giepmans BN, von Herrath MG, Hyoty $\mathrm{H}$, et al. Re-addressing the 2013 consensus guidelines for the diagnosis of insulitis in human type 1 diabetes: is change necessary? Diabetologia. 2017 Apr;60(4):753-5. PubMed PMID: 28070616. Pubmed Central PMCID: PMC5415083. Epub 2017/01/11.

53. Culina S, Lalanne AI, Afonso G, Cerosaletti K, Pinto S, Sebastiani G, et al. Isletreactive $\mathrm{CD} 8+\mathrm{T}$ cell frequencies in the pancreas, but not in blood, distinguish type 1 diabetic patients from healthy donors. Sci Immunol. 2018 Feb 2;3(20):eaa04013. PubMed PMID: 29429978.

54. Gonzalez-Duque S, Azoury ME, Colli ML, Afonso G, Turatsinze J-V, Nigi L, et al. Conventional and neo-antigenic peptides presented by beta cells are targeted by circulating naïve CD8+ T cells in type 1 diabetic and healthy donors. . Cell metabolism. 2018;in press. 55. Arif S, Tree TI, Astill TP, Tremble JM, Bishop AJ, Dayan CM, et al. Autoreactive T cell responses show proinflammatory polarization in diabetes but a regulatory phenotype in health. J Clin Invest. 2004;113(3):451-63.

56. Brusko TM, Wasserfall CH, Clare-Salzler MJ, Schatz DA, Atkinson MA. Functional defects and the influence of age on the frequency of CD4+ CD25+ T-cells in type 1 diabetes. Diabetes. 2005 May;54(5):1407-14. PubMed PMID: 15855327.

57. Legoux FP, Lim JB, Cauley AW, Dikiy S, Ertelt J, Mariani TJ, et al. CD4+ T Cell Tolerance to Tissue-Restricted Self Antigens Is Mediated by Antigen-Specific Regulatory $T$ Cells Rather Than Deletion. Immunity. 2015 Nov 17;43(5):896-908. PubMed PMID: 26572061. Pubmed Central PMCID: 4654997.

58. Malhotra D, Linehan JL, Dileepan T, Lee YJ, Purtha WE, Lu JV, et al. Tolerance is established in polyclonal CD4(+) T cells by distinct mechanisms, according to self-peptide 
expression patterns. Nat Immunol. 2016 Feb;17(2):187-95. PubMed PMID: 26726812. Pubmed Central PMCID: 4718891.

59. Sims EK, Chaudhry Z, Watkins R, Syed F, Blum J, Ouyang F, et al. Elevations in the Fasting Serum Proinsulin-to-C-Peptide Ratio Precede the Onset of Type 1 Diabetes. Diabetes care. 2016 Sep;39(9):1519-26. PubMed PMID: 27385327. Pubmed Central PMCID: PMC5001142.

60. Fava D, Gardner S, Pyke D, Leslie RD. Evidence that the age at diagnosis of IDDM is genetically determined. Diabetes care. 1998 Jun;21(6):925-9. PubMed PMID: 9614609.

61. Redondo MJ, Yu L, Hawa M, Mackenzie T, Pyke DA, Eisenbarth GS, et al. Heterogeneity of type I diabetes: analysis of monozygotic twins in Great Britain and the United States. Diabetologia. 2001;44(3):354-62.

62. Howson JM, Cooper JD, Smyth DJ, Walker NM, Stevens H, She JX, et al. Evidence of gene-gene interaction and age-at-diagnosis effects in type 1 diabetes. Diabetes. 2012 Nov;61(11):3012-7. PubMed PMID: 22891215. Pubmed Central PMCID: 3478521.

63. Inshaw JRJ, Walker NM, Wallace C, Bottolo L, Todd JA. The chromosome 6q22.33 region is associated with age at diagnosis of type 1 diabetes and disease risk in those diagnosed under 5 years of age. Diabetologia. 2018 Jan;61(1):147-57. PubMed PMID: 28983737. Pubmed Central PMCID: 5719131.

64. Cerutti F, Bruno G, Chiarelli F, Lorini R, Meschi F, Sacchetti C, et al. Younger age at onset and sex predict celiac disease in children and adolescents with type 1 diabetes: an Italian multicenter study. Diabetes care. 2004 Jun;27(6):1294-8. PubMed PMID: 15161778. 65. Howson JM, Rosinger S, Smyth DJ, Boehm BO, Group A-ES, Todd JA. Genetic analysis of adult-onset autoimmune diabetes. Diabetes. 2011 Oct;60(10):2645-53. PubMed PMID: 21873553. Pubmed Central PMCID: 3178303.

66. Frohnert BI, Ide L, Dong F, Baron AE, Steck AK, Norris JM, et al. Late-onset islet autoimmunity in childhood: the Diabetes Autoimmunity Study in the Young (DAISY). Diabetologia. 2017 Mar 17. PubMed PMID: 28314946.

67. Mishra R, Chesi A, Cousminer DL, Hawa MI, Bradfield JP, Hodge KM, et al. Relative contribution of type 1 and type 2 diabetes loci to the genetic etiology of adult-onset, noninsulin-requiring autoimmune diabetes. BMC medicine. 2017 Apr 25;15(1):88. PubMed PMID: 28438156. Pubmed Central PMCID: 5404312.

68. Redondo MJ, Oram RA, Steck AK. Genetic Risk Scores for Type 1 Diabetes Prediction and Diagnosis. Current diabetes reports. 2017 Oct 28;17(12):129. PubMed PMID: 29080981.

69. Redondo MJ, Geyer S, Steck AK, Sharp S, Wentworth JM, Weedon MN, et al. A Type 1 Diabetes Genetic Risk Score Predicts Progression of Islet Autoimmunity and Development of Type 1 Diabetes in Individuals at Risk. Diabetes care. 2018 Jul 12. PubMed PMID: 30002199. Epub 2018/07/14.

70. Redondo MJ, Grant SF, Davis A, Greenbaum C, Biobank TDE. Dissecting heterogeneity in paediatric Type 1 diabetes: association of TCF7L2 rs7903146 TT and lowrisk human leukocyte antigen (HLA) genotypes. Diabetic medicine : a journal of the British Diabetic Association. 2016 Mar 30. PubMed PMID: 27027642.

71. Redondo MJ, Muniz J, Rodriguez LM, lyer D, Vaziri-Sani F, Haymond MW, et al. Association of TCF7L2 variation with single islet autoantibody expression in children with type 1 diabetes. BMJ Open Diabetes Res Care. 2014;2(1):e000008. PubMed PMID: 25452857. Pubmed Central PMCID: PMC4212574.

72. Redondo MJ, Geyer S, Steck AK, Sosenko J, Anderson M, Antinozzi P, et al. TCF7L2 Genetic Variants Contribute to Phenotypic Heterogeneity of Type 1 Diabetes. Diabetes care. 2018 Feb;41(2):311-7. PubMed PMID: 29025879.

73. Keymeulen B, Walter M, Mathieu C, Kaufman L, Gorus F, Hilbrands R, et al. Fouryear metabolic outcome of a randomised controlled CD3-antibody trial in recent-onset type 1 diabetic patients depends on their age and baseline residual beta cell mass. Diabetologia. 2010 Apr;53(4):614-23. PubMed PMID: 20225393. Epub 2010/03/13.

74. Hagopian W, Ferry RJ, Jr., Sherry N, Carlin D, Bonvini E, Johnson S, et al. Teplizumab preserves C-peptide in recent-onset type 1 diabetes: two-year results from the 
randomized, placebo-controlled Protege trial. Diabetes. 2013 Nov;62(11):3901-8. PubMed PMID: 23801579. Pubmed Central PMCID: 3806608.

75. Rigby MR, DiMeglio LA, Rendell MS, Felner El, Dostou JM, Gitelman SE, et al. Targeting of memory T cells with alefacept in new-onset type 1 diabetes (T1DAL study): 12 month results of a randomised, double-blind, placebo-controlled phase 2 trial. Lancet Diabetes Endocrinol. 2013 Dec;1(4):284-94. PubMed PMID: 24622414. Pubmed Central PMCID: 3957186. Epub 2014/03/14. eng.

76. Rigby MR, Harris KM, Pinckney A, DiMeglio LA, Rendell MS, Felner El, et al. Alefacept provides sustained clinical and immunological effects in new-onset type 1 diabetes patients. The Journal of clinical investigation. 2015 Aug 3;125(8):3285-96. PubMed PMID: 26193635. Pubmed Central PMCID: PMC4623571. Epub 2015/07/21.

77. Pescovitz MD, Greenbaum CJ, Krause-Steinrauf H, Becker DJ, Gitelman SE, Goland $\mathrm{R}$, et al. Rituximab, B-lymphocyte depletion, and preservation of beta-cell function. The New England journal of medicine. 2009 Nov 26;361(22):2143-52. PubMed PMID: 19940299. Epub 2009/11/27. eng.

78. Orban T, Bundy B, Becker DJ, DiMeglio LA, Gitelman SE, Goland R, et al. Costimulation modulation with abatacept in patients with recent-onset type 1 diabetes: a randomised, double-blind, placebo-controlled trial. Lancet. 2011 Jul 30;378(9789):412-9. PubMed PMID: 21719096. Epub 2011/07/02. eng.

\section{Annotated References}

52. ${ }^{* *}$ Culina S, Lalanne Al, Afonso G, Cerosaletti K, Pinto S, Sebastiani G, et al. Isletreactive $\mathrm{CD} 8+\mathrm{T}$ cell frequencies in the pancreas, but not in blood, distinguish type 1 diabetic patients from healthy donors. Sci Immunol. 2018;3(20):eaao4013.

This paper proposes that a universal state of 'benign' autoimmunity is present in all individuals. The key difference between the islet-reactive CD8+ T cells of T1D and healthy donors is not in their circulating frequency or history of antigen encounter, but in their capacity to home to the pancreas.

37. *Lam CJ, Jacobson DR, Rankin MM, Cox AR, Kushner JA. beta Cells Persist in T1D Pancreata Without Evidence of Ongoing beta-Cell Turnover or Neogenesis. J Clin Endocrinol Metab. 2017;102(8):2647-59.

This study examines the persistence of pancreatic $\beta$ cells in donors with longstanding Type 1 diabetes donors from the nPOD collection and suggests that this is not due to $\beta$ cell regeneration, small islet/ ductal neogenesis or transdifferentiation from other islet cell types.

45. **Leete P, Willcox A, Krogvold L, Dahl-Jørgensen K, Foulis AK, Richardson SJ, et al. Differential insulitic profiles determine the extent of beta cell destruction and the age at onset of type 1 diabetes. Diabetes. 2016.

${ }^{* *}$ This study demonstrates that age of onset of Type 1 diabetes (in recent-onset cases) is associated with different insulitic islet immune cell profiles and extent of pancreatic $\beta$-cell destruction.

62. **Inshaw, J. R. J., Walker, N. M., Wallace, C., Bottolo, L., and Todd, J. A. (2018) The chromosome $6 \mathrm{q} 22.33$ region is associated with age at diagnosis of type 1 diabetes and disease risk in those diagnosed under 5 years of age. Diabetologia61, 147-157 
This study systematically analyzed associations between genetic factors and age of clinical diagnosis of type 1 diabetes. 